\title{
Recent Contributions of Agricultural Economics Research in the Field of Sustainable Development
}

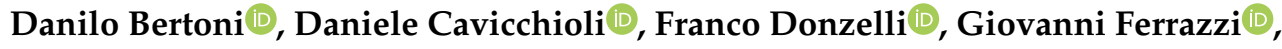 \\ Dario G. Frisio $\mathbb{D}^{\text {, Roberto Pretolani }} \mathbb{D}^{\mathbb{D}}$, Elena Claire Ricci ${ }^{*} \mathbb{D}$ and Vera Ventura \\ Department of Environmental Science and Policy, University of Milan, 20133 Milano, Italy; \\ danilo.bertoni@unimi.it (D.B.); daniele.cavicchioli@unimi.it (D.C.); franco.donzelli@unimi.it (F.D.); \\ giovanni.ferrazzi@unimi.it (G.F.); dario.frisio@unimi.it (D.G.F.); roberto.pretolani@unimi.it (R.P.); \\ vera.ventura@unimi.it (V.V.) \\ * Correspondence: elenaclaire.ricci@unimi.it; Tel.: +39-02-5031-6497
}

Received: 3 November 2018; Accepted: 8 December 2018; Published: 14 December 2018 updates

\begin{abstract}
Sustainable development is more often considered by media, public opinion, and politicians to be the main goal our society should attempt to pursue in the coming years. To this aim, academic researchers have made sustainability one of the main objects of their studies. This work focuses on environmental sustainability and presents a brief overview of how it is taken into consideration in the agricultural economics field by considering this topic from different perspectives and thus highlighting how this field is gradually broadening its scope to include sustainable development objectives. Our analysis shows that the path towards sustainable development is strongly correlated to the protection of the environment. Therefore, agricultural policies aimed at protecting and preserving the environment, and, more in general, innovation along the agri-food chain, together with consumer attention towards environmental issues, can play an important role in achieving this objective.
\end{abstract}

Keywords: agri-food economics; environmental sustainability; agriculture; agbiotech; consumer; migration

\section{Introduction}

Recently, the word "sustainability" has increasingly attracted the attention of worldwide media, politicians and public opinion. The dramatic changes occurred in the last decades in global society, and the increasing awareness for the potential future damages associated to these changes, have led to a convergence of efforts by countries toward finding a global governance that is aimed at promoting sustainable development. To this aim, the United Nations in 2015 have defined 17 Sustainable Development Goals (SDGs) to which the signatory countries (more than 150) commit to pursuing by the year 2030. The 17 Development Goals are: 1-No poverty; 2-Zero hunger; 3-Good health and well-being; 4-Quality education; 5-Gender equality; 6-Clean water and sanitation; 7-Affordable and clean energy; 8-Decent work and economic growth; 9-Industry innovation and infrastructure; 10-Reduced inequality; 11-Sustainable cities and communities; 12-Responsible consumption and production; 13-Climate action; 14-Life below water; 15-Life on land; 16-Peace and justice strong institution; 17-Partnerships for the goals. The 17 SDGs encompass 169 targets concerning different relevant issues for the future of worldwide society. However, it is worth noting that these goals are strictly interconnected with each other, as the effort toward the enhancement of one of them, can certainly be beneficial to the improvement of other goals.

The objective of this review is to provide a quite comprehensive perspective of the way in which studies in the agricultural economic field are analyzing sustainability issues. Agricultural economics can be defined as "the application of the social science of economics to the field of agriculture" [1]. 
However, given the multifunctional role covered by agriculture, the fields of study covered by researchers actually encompass several topics, such as food and consumer economics, production and farm management economics, and development economics. The background idea is to show how, lately, agri-food economists have increasingly included among their aims a wider evaluation of the impacts of production and consumption choices by accepting the challenge of "greening" agri-food value chains. Since its introduction in the 1987 United Nations Brundtland Report, the concept of sustainable development has received multidisciplinary consideration [2]. According to Cortese [3], sustainable development is multidisciplinary in its nature and should not be considered monolithically, but rather in a more holistic way by promoting interdisciplinary understanding and collaboration [4]. From this perspective, the multidisciplinary approach of the agricultural economic research seems to perfectly fit the study of sustainable development.

Overall, researchers identified three main dimensions of sustainability: economic, environmental, and social development. Despite their differences, these three main pillars should be considered correlated and complementary. While most of the previous papers in the literature highlight the multidisciplinary feature of sustainable development by exploring the way in which the three main pillars interact with each other [5-7], in this article we focus in particular on the economic dimension of sustainability. While worldwide countries usually set economic growth as their primary interest, this often contrasts with an actual improvement in the other two pillars of sustainable development. From this perspective, the contribution of several agricultural economics studies in the last few years has been aimed at reconciling economic development with environmental and social development. Hence, agricultural economics studies, touching several different topics related to sustainability, directly or indirectly, can provide a significant contribution in the next few years toward the achievement of the aforementioned Sustainable Development Goals.

Sustainable development studies in agricultural economics have particularly explored the link between agriculture and the environment. While sustainable development and environment can be directly associated to some of the SDGs, there are a number of reasons why agriculture (and agri-food chains) can be associated to them, though indirectly. For example, agriculture represents the primary source of income in many developing countries. From this perspective, a growth in the agricultural sector may in turn lead to an improvement in wealth and health conditions in these countries, to better working conditions, and, thus ultimately, to economic growth; while, on the contrary, a negative shock affecting agriculture may induce a decrease in socio-economic outcomes (i.e., labor mobility-migration). Agriculture has a strong link with the environment due, on the one hand, to the use of natural resources (such as land and water) as a production inputs, and, on the other hand, to the emission of different pollutants and the effects caused by the change in environmental conditions due to agricultural activities. More in detail, the case of greenhouse gas emission is particularly interesting as agriculture is both a major sink of carbon, at least in the short-medium term, but also a major source of emissions, especially in relation to the use of energy-intensive chemicals and to land and animal-stock management [8].

The review presented in this work shows the way in which a selection of agricultural economics fields of study have explored some of these issues. In particular, we first consider the role played by agricultural and agro-energy policies in promoting sustainable development by looking in particular at the case of the European Union (EU) Common Agricultural Policy (CAP). We then move to analyze how innovation can lead to an improvement in the sustainability of agricultural practices and food consumption by looking in particular to the role played by agbiotech innovation and the conversion of food wastes. We then shift our attention to the consumer side, by analyzing the importance attached by consumers to environmental sustainability issues when making their food choices. Finally, we consider the literature considering the effects of climate change in inducing migration flows, which can be seen as a possible variation in socio-economic outcomes by looking in particular to the role played by agriculture in affecting such a relationship. 
This review does not focus on a specific topic, but instead tries to shed some light on the different angles through which the concept of sustainable development can be studied from an economic perspective. Sustainability is a very heterogeneous and complex issue, and for this reason, should be tackled through a multidisciplinary and holistic approach. We believe that the selected topics are among those with a higher potential to be exploited toward the achievement of sustainable development goals.

\section{Evolving Agricultural and Agro-Energy Policy toward a Sustainability Path}

This section explores how specific sectoral policies, such as the Common Agricultural Policy (CAP) and the policies for renewable energies related to agriculture (e.g., related to biogas) has evolved over time and how they have been informed by and adapted to the concepts of environmental sustainability. At the same time, we highlight how research has contributed to the assessment of the impacts of agricultural and agro-energy policies on agricultural systems and discuss some policy implications. Research evidence and related policy recommendations are selected accordingly.

The concept of sustainable development dates back to the so-called Brundtland Report [9] and has been organised among others, in three main domains (or dimensions) of sustainability: economic, social, and environmental. Since 1987, such a concept has gradually shaped public policies in various sectors, including the agricultural and agro-energy ones. The Common Agricultural Policy of the European Union, which was introduced at the beginning of the 1960's, has evolved according to societal changes and demands, especially in terms of its targets and implementation tools. In particular, the target of increasing agricultural productivity (in order to assure food self-sufficiency) has been progressively replaced by measures aimed at fostering agricultural sustainability and environmentally friendly practices in farming. The first notable step of such a process took place with the institution of the "second pillar" of the CAP, aimed at recognizing and rewarding various multi-functional and environmentally friendly practices in farming. Within the second pillar, the most relevant actions to encourage sustainable farming practices are the agri-environmental measures (AEMs henceforth). As the participation in AEMs (and in other measures of the second pillar) is voluntary for farmers, it is crucial to understand what factors encourage their uptake. This aspect has been explored by Defrancesco et al. [10], Bertoni et al. [11], Burton [12], Franzén et al. [13], and Pavlis et al. [14], and compare farm, farmer, and territorial characteristics of all subjects that take part and do not take part toward AEMs. What commonly emerges from these studies is that younger farmers are more inclined towards sustainable farming practices. Furthermore, the adverse selection effect, according to which the lower the adaptation cost to comply with AEMs, the higher is the probability to participate in the scheme, is confirmed. This, in turn, leads to a lack of additionality in the effect of these policies, as the farmers representing the real target of these policies are less likely to participate. Finally, the location of the farm in environmentally sensitive areas does not seem to affect the uptake of AEMs. Such a finding points to a lack of territorial targeting of this kind of intervention. Beyond the participation in environmentally friendly farming practices, it is crucial to assess whether and to what extent the adoption of such actions actually translates into the expected outcomes. In this regard, the agricultural economics research has focused on developing tools and farm-level analyses based on sample survey simulations [15-17] and on ex-post estimations [18-20] on the effects of both farm practices and agricultural policies on sustainability.

As the concept of sustainable development also takes into consideration the social and economic dimensions (along with the environmental one), the effects of agricultural policy have also been examined in terms of labor creation (intended as a reduction of out-farm migration). Using data from European regions over the period 1990 to 2009, Olper et al. [21] found that agricultural payments contribute to reduce farm labor migration, even if with a moderate effect. However, it is worth noting that, during an economic downturn, off-farm employment may represent a useful strategy to integrate family farm income [22]. In this regard, first pillar payments are more effective than second pillar ones, and within the former, coupled payments are more effective than decoupled ones. Even if decoupled 
payments emerged as the most effective policy instrument to keep labor within the agricultural sector, the current CAP reform has bounded them to the accomplishment of the so called "greening measures" by beneficiary farmers [23]. Such measures consist in crop diversification, allocation of a minimum share $(5-7 \%)$ of farmland to ecological focus areas, and maintenance of permanent grasslands and pastures. Even if the debate around the CAP reform has sometimes defined the current greening measures as being a "low-profile compromise," their impact assessment has indicated that they have had quite a strong effect for farm and crop mixes in high intensity agricultural systems, while other areas are not affected by the policy instrument $[24,25]$. For instance, considering the plain area of the Lombardy region, which is one of the most intensive farming contexts in Europe [26], as a case study, Cavicchioli and Bertoni [27] measured the ex-ante impact of greening measures on $33 \%$ of farms and $72 \%$ of used agricultural area (30,000 hectares), finding a decrease in cereals in favor of nitrogen-fixing crops, with an estimated loss of 9.2 million euros. According to the same analysis, greening measures contained in the Commission Proposal, would have had a stronger impact on Lombardy agriculture, as compared to the approved measures. Such results are consistent with other ex-ante simulations carried out in the Lombardy region, using farm-level accountancy data [28-30]. Comparing the effect of greening measures on three different dairy farms structures (extensive, organic, and intensive), Gaudino and others [31] found a more intense effect, in terms of income reduction, for intensive farms, compared to the other two categories. The strong effect of greening on Lombardy agriculture seems to be confirmed, in terms of crop mix change, where Bertoni et al. [32] found a significant discontinuity in farmland use transition in Lombardy before (2011-2014) and after (2015-2016) the adoption of greening. Even if such preliminary analysis does not measure the net impact of greening, its results are in line with most ex-ante simulations in the same region.

Policies to incentive bio-energy and biofuel crops may also have an impact on the sustainability of agricultural systems, sometimes not in the desired direction [33,34]. The case of biogas in high-intensity agricultural areas of Italy represents an emblematic example of how badly-designed policies may lead to distortive effects on the agricultural system. In a first stage, biogas incentives were targeted toward big-sized plants, while, after observing side effects, the policy changed in favor of smaller-sized plants. Through a simulation of the feedstock maize market, Bartoli et al. [35] showed that payments for big-sized biogas plants lead to a distortion of the feed market with an increase in costs for livestock farms. Such an effect was reduced when incentives were given to smaller-sized biogas plants. Using data on farmland values where biogas plants were more present, Demartini et al. [36] showed a significant increase in rental prices over the period when big-sized plants received incentives, while such an effect disappeared when smaller-sized plants were subsidized.

The lesson learned from this brief analysis points to some general warning for agricultural policymakers. Primarily, interventions aimed at fostering environmental sustainability may incur some unintended outcomes. On the one hand, a lack of response and territorial targeting for voluntary measures (see the adverse selection for AEMs) may decrease the effectiveness of environmental payments. On the other side, bounding direct payments to environmental practices (such as the greening of the first pillar) may weaken the social and economic sustainability of high-intensity agricultural systems. Second, the lack of territorial targeting of environmentally friendly payments (both voluntary and direct ones) may be due to a farm level design of such instruments. Finally, (badly designed) incentives toward renewable energy may have different outcomes on the three pillars of sustainable development in agriculture, improving the environmental component, but distorting some product (feed) and factor (land) markets. Such issues may be addressed by setting up the monitoring of sustainability indicators of the agricultural system in order to forecast (ex-ante) and measure (ex-post) their territorial response to different policies. The availability of a framework for efficient indicators to quantify agriculture sustainability, in all of its facets, is the key element toward integrating the concept of sustainability into policy planning. In this sense, some attempts to measure the social, environmental, and economic sustainability of agriculture have already been proposed both at the farm level [15,37-42] and at the territorial level [43-45]. Such efforts should be increased and empowered by 
better exploiting and integrating all the available geo-referenced databases related to the three pillars of agricultural sustainability.

\section{Innovative Strategies for a More Sustainable Agri-Food Chain}

\subsection{Agbiotech Innovation for Sustainable Agriculture}

In the scenario of the global challenges that modern agriculture needs to consider, new plant breeding technologies (NPBTs) represent one of the most promising tools for the implementation of new plant varieties able to improve field productivity and agricultural sustainability [46]. This set of techniques-including cisgenesis, genome editing, and targeted mutagenesis, amongst others-are emerging rapidly from advances in genomic research for applications in crop improvement. They enable precise and targeted changes in the genome [47]. Modern agriculture can benefit from the introduction of NPBT for their impact in the reduction of pesticide use [48], the adaptation to changing climatic conditions [49], and the control of production losses [50]. In addition, products derived from NPBT can potentially mitigate public aversion for genetic modification in plants and food, mainly due to the fact that these new technologies are perceived as more natural with respect to the "old" transgenic approach producing genetically modified plants [51]. Hence, the economic evaluation of the innovative products can provide evidence of the real economic feasibility of new solutions, and their concrete contribution to a more sustainable agriculture. This specific innovation sector is suited to be studied using patent data [52-57] on agbiotech patents granted internationally, by disentangling the role of private, public, and private-public collaborations in producing agbiotech innovations. Frisio et al. [58] evaluated the agbiotech patent landscape for genetically modified (GM) innovations, showing that the private sector played a major role in the overall production of agbiotech patents, while the public sector is specialized in fundamental research fields. Egelie et al. [59] discussed the control of the CRISPR-Cas technology for plant improvement and the implication of intellectual property management over the exploitation of innovation at the commercial level. Some other authors proposed to examine the cognitive framing of innovation that shapes decisions of the actors in the innovation chain [60], suggesting alternative methods for the estimation of innovation apart from inputs and outputs (research and development funding and patents).

The evaluation of the socio-economic impacts of NPBTs plants and products can also support multidisciplinary research activities, as in the cost action "iPlanta: modifying plants to produce interfering RNA," whose main objective is to examine the scientific challenges in manipulating RNAi production for disease and pest control and metabolic enhancement of plants for the achievement of more sustainable and integrated crop production systems.

\subsection{Food Waste Reduction}

Reducing food waste can help to increase the sustainability of the food system, given that the generation of food loss and waste has negative environmental impacts because of the water, land, energy, and other natural resources used to produce the wasted food.

It is worth mentioning that there exist multiple valuable strategies to reduce food waste based on the EU food waste hierarchy (Figure 1). In particular, if we consider that about one third of the food produced worldwide is wasted, the most straightforward strategy to reduce this phenomenon would be to create a more equitable food-distribution system that can meet food demand and supply, avoiding a large loss of resources. Indeed, the top three strategies (prevention, donation, and animal feed) are the ones that received greatest attention by the economic research, being the most preferable from an economic and environmental perspective [61,62]. 

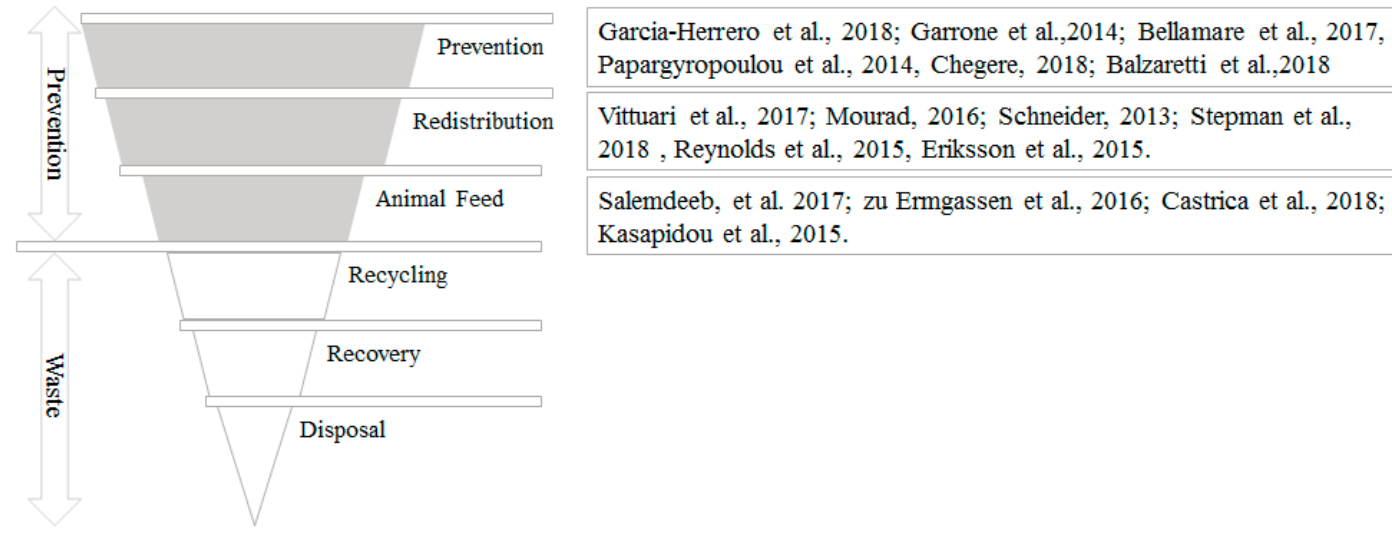

Figure 1. Food waste hierarchy and relevant literature.

The first action, reducing waste generation, includes the development of new frameworks for food waste measurement $[63,64]$ and management $[65,66]$, together with more empirical studies focused on specific levels of the food chain $[67,68]$. As for the second-most preferable action, namely food donation, several studies have shown that they offer a limited contribution to food waste prevention [69], probably due to political, social, and logistical barriers during implementation [70,71]. Other authors suggested that actors with different interests in food commodity chains can potentially develop competing solutions [72]. Nevertheless, other studies confirm that food donation is a sustainable practice from the environmental and economic perspectives [61,62].

The third action, the re-use of food surplus for animal feed, is part of the strategies targeted at tackling food waste, in accordance with the waste management hierarchy proposed by the European Waste Framework Directive (EC 2008/98) [73]. Nevertheless, the current legal framework in the European Union (EU) strongly restricts the possibility of using food waste for this purpose because of food safety issues related to previous food scandals (EC2009/1069) [74]. Due to the magnitude of the related ethical and economic issues, the scientific literature has increasingly focused on the impact of waste treatment strategies for feed production; $\mathrm{Zu}$ et al. [75] stated that a change in EU legislation to allow the use of food waste as animal feed could save 1.8 million hectares of agricultural land. According to Salemdeeb et al. [76], converting food waste into animal feed is a more sustainable practice when compared to existing technologies for food waste processing as anaerobic digestion and composting. The work by Castrica et al. [77] evaluated the feasibility of innovative measures for feed production in the EU with the aim of identifying the best strategies to implement within the current EU legal framework for waste management. Results suggest that the implementation of feed-from-food measures to reduce food waste in Europe is already possible and does not need to wait for further policy interventions. The conversion of food surplus in pet food can be one of the most concrete strategies for using food waste within the European context, and the reduced competition amongst food/feed/energy crop use could mitigate the environmental impacts of feed production and waste generation [78].

\subsection{Increasing the Sustainability of Food Production}

Food production is one of the economic activities that poses major pressures on the environment $[79,80]$. Focusing on climate change, which is one of the major challenges that society is facing, agriculture, forestry, and land use change are responsible for $20-24 \%$ of global greenhouse gas emissions [8]. The agri-environmental measures, like those discussed in Section 2, may be important polices to foster the adoption of more environmentally friendly and climate-friendly agricultural practices that may produce significant changes in the levels of pollution and greenhouse-gas emissions [81]. Indeed, mitigation strategies for the agri-food sector are related to land and livestock management, to the use of energy-intense chemicals, and to changes in dietary patterns. In this latter direction, as it will be discussed in the next section, consumers may also play an important role. Indeed, 
estimates on world population growth indicate that the food system in the coming years will have to feed an additional three billion people [82]. Moreover, as income levels around the world grow with development, dietary patters also change. Evidence from the literature highlights how such changes in developing countries tend to favor the inclusion of more animal-based products in the diet [83]. Indeed, as highlighted by Delgado et al. [84], developing countries are rapidly increasing the amount of animal-based products in their diets (with annual growth values of 5.4\% between 1982-1994 and of 2.8\% from 1993 onwards); however, they still remain behind the levels of developed countries ( $11 \%$ of calories from animal food products compared to $27 \%$, and $26 \%$ of proteins compared to $56 \%$ ). If pro-capita consumption of animal-based products in less-developed countries was to catch up with that if developed countries, this would imply a tremendous increase in global meat production, which has already exceeded 300 million tonnes per year (FAOSTAT 2017), and the environmental impacts of diets. Literature has indeed highlighted how animal production and especially beef has the highest environmental impacts $[85,86]$ due to the large amount of arable land, water, and raw material needed for its production [87]. Indeed, a study by de Vries and de Boer [38] estimated, on the basis of a meta-analysis of previous studies, that the production of $1 \mathrm{~kg}$ of beef is the most land and energy intensive production and also the one with the highest global warming potential (GWP), with pork and chicken meat following beef. According to Steifeld et al. [88] Steinfeld et al. [89], such a strong GWP is related to fossil fuel use, deforestation, methane emissions by the livestock, and the emissions by fertilizers. This can be reduced by changing feed, the intensity of production, improving animal productivity and fertility, and other farming practices [90]. More in detail, studies have compared the greenhouse gas emissions of livestock, especially bovine animals, that were managed in different ways. An analysis by Capper [91] highlights how the impacts of beef production have been reduced in the last 30 to 40 years; however, there is still room for improvement. Indeed, studies by Pelletier et al. [92] and by Casey and Holden [93] show how different production strategies (also connected to EU agri-environmental measures or other food policies in the case of Ireland) can lead to different impacts per $\mathrm{kg}$ of beef or per land unit, focusing on two specific case-studies in the USA and Ireland, respectively. However, it is a complex issue that needs to be addressed and analyzed with a wide perspective, taking into account all direct and indirect impacts to be able to find efficient policies to reduce the impact of animal-based food products $[87,94]$. For example, in addition to trying to mitigate the environmental and climate impacts of meat production, as for food waste (Section 3.2), it is important to work not only at managing the problem but also on reducing its source. In this direction, dietary changes reducing the amount of meat consumed going towards more plant-based diets can make a big difference for the environmental impacts of the food system and also have some positive effects on consumer health $[95,96]$. Discussion on the role of consumers in affecting the sustainability of the food system and the importance of their engagement on the matter is discussed in the next section.

\section{Consumer Preferences for Environmental Sustainability Attributes}

Sustainable development goals cannot be fully reached unless action is taken on all fronts and by all actors. In this direction, consumers play an important role. Indeed, literature is increasingly highlighting how citizens/consumers need to be involved in finding and pursuing sustainable development goals $[85,94,97]$. The 2030 Agenda for Sustainable Development of the United Nations includes a sustainable development goal specifically targeting sustainable consumption and production (SDG12). Thus, highlighting how the sustainability of economic activities, including the food sector, is not only a matter of changing production methods, but also consumption patterns.

Consumers may have a role on the sustainability of the food system by altering their food choices both in terms of dietary shifts and of choice among similar products with different sustainability-related attributes [98]. Changes in consumer preferences may also steer new production methods and the research for new innovative and sustainable food products. Indeed, given the new aggregation possibilities provided by information and communication technologies, final consumers are able to collect and share much more information about current performances by food firms and are potentially 
more able to distinguish more sustainable food chains from less sustainable ones, with potential effects on firm reputation. Consumers are also citizens and thus they can give signals to policymakers such that sustainable development can become higher in the political agenda [99]. Moreover, consumers may also play a role in accepting (or not) new food technologies that might reduce the impacts of food production $[100,101]$.

In this context, it is important to study consumer attitudes and preferences towards environmental sustainability [102]. Within the agri-food economics literature, an increasing number of papers are studying whether environmental sustainability issues are taken into consideration by consumers while making food choices [89,98,103-105]. Different approaches are adopted. Choice experiment-based studies are centered in finding how environmental attributes might affect food choices. Indeed, many experiments have been done to investigate the trade-off among different attributes [106]. For example, Hu et al. [107] jointly evaluate attributes related to health, environmental sustainability, and genetic modifications. Caputo et al. [108] evaluate willingness to pay values for carbon labels and food mileage indications. Consumer attention for greenhouse gas emissions related to food products has also been investigated by other scholars $[109,110]$.

Other studies are instead more focused on studying the antecedents of environmentally sustainable choices. Many of these studies are set within the theory of planned behavior (TPB) framework whose assumption is that behavioral intentions are related to consumer attitudes, subjective norms, and perceived behavioral control [111]. Other antecedents of the intention of performing an environmentally sustainable food-related behavior are related to environmental concern, environmental or sustainability knowledge, and general environmental behavior [112-115]. In general, results suggest that the higher the concern, knowledge, and environmental behavior on other aspects, the more likely consumers are to engage in sustainable food choices. Other studies have focused on trust [116,117]. For example, Nuttavuthisit and Thogersen [118] highlight how trust is essential in the case of green products with credence attributes [104]. A paper by Ricci et al. [119] confirms such results in the particular case of convenience food with environmentally sustainable attributes. This is particularly interesting because convenience food is gaining more and more importance among consumers, especially in urban areas, due to their time-saving services [120], but such products are often considered unsustainable [121].

Nudge-based research, instead, analyzes to what extent changes in the choice architecture via informational and non-informational cues affects environmentally sustainable food choices. The idea behind nudges is to stimulate citizens/consumers to take choices that are better for them using prompts that do not call for extensive cognitive evaluations or consideration of one's own values or attitudes, but more rapid intuitive responses [122]. Experiments are often done in the field either at restaurants, canteens, or shops by working on product positioning, menu design, plate size, and other initiatives. For example, some researchers have targeted vegetarian choices in a restaurant working on saliency of the vegetarian option [123,124]. De Boer et al. [125] instead focused on plate size and on "veggy-days" initiatives. Other researchers focused on carbon labelling [126,127]. For example, Brunner et al. [128] studied the effects of a traffic-light labelling on menus providing information on the greenhouse-gas emissions related to the available dishes. Results from these types of studies vary quite substantially, with some studies finding favorable results and others finding minimal changes, especially in the long term. However, more research is needed in this field as nudge-based studies on environmental sustainability issues are still very limited.

Another difference in the literature is related to the focus of the various studies. Some papers are very general in their scope, others focus on specific sustainability attributes available on different products, or on specific types of products. More in detail, the most-studied topic is related to consumer preferences for agricultural practices, in relation to organic products [129-133]. Fishery products have also been studied quite widely [134-136]. Other work has focused more specifically on wine, meat, chocolate, coffee, and other products [137-141]. Some studies are also starting to investigate the willingness to make dietary changes, and in particular, to reduce meat consumption 
to favor the environment. Studies have focused on consumer preferences for different attributes of meat and plant-based products [142], others on consumer perception and attitudes and beliefs about vegetarianism and meat consumption [143,144], and on eating motives [145]. As discussed in Section 3.3, this has a strong potential for reducing several externalities that the current food system imposes on society.

Consumers may have an effect on the sustainability of the food system not only by focusing on the choices among products, but also changing their purchasing and consumption behavior to reduce household food waste [146,147]. Indeed, as highlighted in the previous section, in recent years the economic literature has devoted much attention to evaluating the impacts of the different available strategies in order to prevent waste generation, i.e., work at the highest levels of the waste hierarchy (Figure 1). More in detail, the research focuses on what might be the behaviors or the motivations that generate food waste [148-150]. Results indicate that building consumer knowledge may be a useful means to reduce waste at the consumer level [151]. Recent literature highlights the role of labelling and the related levels of consumer understanding and trust in labelled information in reducing household food waste [152,153].

What emerges from these consumer studies is that there are segments of the population that are interested in the environmental sustainability of their food choices. Many papers highlight that those who are female, richer, and more educated tend to be more sensitive to these issues. Age has been found to have both positive and negative associations. Indeed, some studies find that older people care more for the environment, possibly because they have fewer budgetary constraints and more time, while others find that younger people are more sensitive, possibly because they have had a stronger education regarding sustainability issues. However, other studies highlight how socio-demographic characteristics are less important than more value-based variables. A common result that often emerges is that there is an attitude-behavior gap $[89,154,155]$ between people's attitude and intentions towards environmental sustainable food choices and their actual behavior. This could be related to budget constraints, low availability of sustainable options, lack of procedural knowledge, and inability to distinguish between products with different levels of sustainability attributes, lack of time, and other potential barriers that need to be addressed in order to support the transition towards more environmentally sustainable food choices.

\section{Migration and Climate Change}

Goals 1, 8, and 13 of the Sustainable Development Goals are related to avoiding poverty, creating better working conditions and economic growth, and studying how climate change may be controlled thought specific actions, respectively. Hence, studying the link between climate change and migration can be considered a step forward in understanding the impacts of environmental variations on socio-economic outcomes such as human mobility and/or poverty [156].

One of the main channels through which climate change may affect internal or international migration is agriculture since, as outlined in detail by the empirical literature, it is the sector most affected by weather variations $[157,158]$.

As described in Figure 2, we can consider climate change as an exogenous shock that may impact agriculture (i.e., agricultural productivity), which is the channel through which variations in temperature and precipitations force individuals to move.

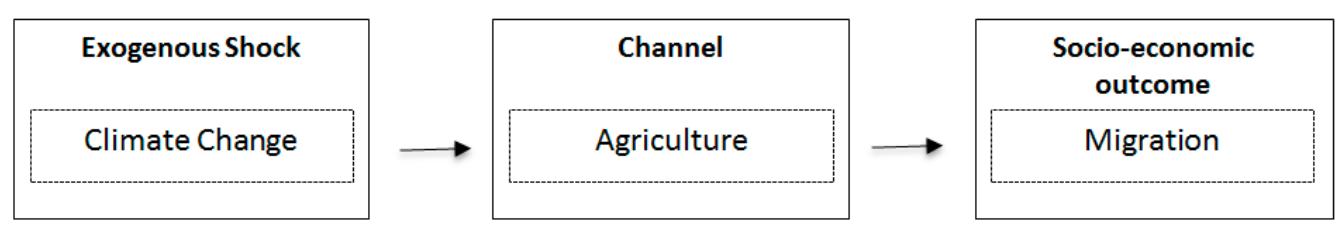

Figure 2. The effect of climate change on migration throughout the agricultural channel. 
Even if in the last years, both international organizations and political institutions have underlined the key role of climate change on human mobility, studies on the empirical evidence linking climate change and migration are still in a preliminary phase. This is because, while it could be easily documented that a link between climate change and human mobility exists, it is more complex to deeply understand the mechanisms behind this link, since the impact of climatic shocks depend on both their intensity and the fact that climate change may affect migration either directly, or indirectly through other factors (i.e., the agricultural channel proposed in Figure 2).

In general, the motivation behind the decision to migrate, either within the country or internationally, is driven by the possibility to increase the individual's or the family's income $[159,160]$, to reunite with other family members, or to run away from origin countries where there are conflicts or inadequate political institutions [161]. An additional category concerns those that the literature calls "environmental migrants," that are individuals who consider migration as a possible insurance mechanism toward natural disasters and weather variations if they do not have alternative adaptation strategies and specific liquidity constraints [162].

Falco et al. [163] provide an overview of the recent literature on climate change and migration and on the empirical econometric methods applied in this field. In principle, the authors describe the literature on the economic effects of climate change on agriculture through the econometric methods adopted for the analysis: integrated agro-economic models, Ricardian models, or time-series and panel models [164-166]. Hence, they present some of the main contributions on the impact of climate shocks on both internal and international migration; therefore, they present a review of the literature differentiating between micro and macro studies. In general, they show that the importance of agriculture emerges from both microlevel country studies and macrolevel analyses using cross-sectional data over longer time periods. Thus, "policy actions targeted to sustainable agriculture and rural development can both help tackle the challenges posed by climate change and create opportunities in the face of growing migration issues" [163]. However, they also emphasized that much of the evidence is based on statistical correlations, which do not imply causal inferences; hence, further research should use a more structural approach and more sophisticated research designs.

In line with the idea above, the work by Falco et al. [167] tries to fill this gap. They find, empirically, that negative agricultural (outcome) variations due to an increase in temperature and precipitations are possible motivations behind the individual's (or family's) decision to move $[156,168]$. This is because agricultural outcomes are one of the main sources of income, especially in developing countries where most migrants are coming from, and also because agriculture is, by far, the sector most affected by climate variations, since short- and long-term effects of climate change have significant impacts on agricultural productivity [169], rural livelihoods, and food security worldwide [170-172]. Using a data set of more than 150 countries from 1960 to 2010, they use a two-stage least square (2SLS) approach to test if there exists a causal relationship between changes in agricultural conditions and international migration. Their results provide convincing support that negative shocks in agricultural productivity, induced in particular by a long-run increase in temperature and precipitations, positively affect net migration outflows in middle-poor countries.

Another conceptual step toward a deeper understanding of the role of agriculture in mediating the relationship between migration and climate change may be represented by the addition of the conflict argument in the framework described above. Given the results from Falco et al. [167], conflicts can be considered as an individual migration pushing factor as a consequence of agricultural shocks due to climate variations [173-175]. A possible idea may be to implement an econometric estimation to examine whether an increase in temperature and precipitations may negatively affect agricultural productivity and hence may generate conflicts and/or induce individuals to leave the country and became asylum applicants.

An additional contribution to address the issues described above may be to employ a well-known approach in the international trade literature in the migration literature, namely dealing with zeros in the dataset [176]. Using a two-step Heckman selection framework, the idea is to replicate the 
analysis proposed by Missirian and Schlenker [177]. In fact, adopting a fixed-effect econometric model, linking directly the asylum applications towards EU to the weather variations in the origin countries, the model adds a correction for a sample selection effect, i.e., the inverse Mills ratio derived from the Heckman first stage regression. Future research could also go in the direction of accounting for the heterogeneity in the agricultural sector. Following the micro evidence in Bazzi [178], where an increase in precipitations and rice price shocks increase international migration, particularly in villages with more small landholders, it could be relevant to extend this idea to a generalized gravity framework with a large time period.

\section{Conclusions}

The increasing worldwide attention toward the better protection and preservation of the environment has made sustainability the focus of many academic studies. In particular, agricultural economists in the last few years have concentrated their attention on studying how sustainable development is connected with green agricultural practices and to whole agri-food chains. This paper presents a review of some contributions to this literature coming from studies in the field of agricultural economics that consider from different perspectives how sustainability is actually tied to the environment, agriculture, and food consumption. The main findings, implications, and insights for future research for each of the topics discussed are visually synthesized to help the reader to build a clearer picture of the different perspectives (Appendix A). More specifically, what emerges from our review is that sustainable development is a key driver of agricultural policies, which are more and more oriented to create incentives for a better protection and management of the environment. Along the same line, innovation in the agri-food sectors is attempting to consistently reduce the impact of agricultural production and food consumption on the environment. The importance attached by consumers to sustainability issues plays a key role in the attempt of pursuing Sustainable Development Goals as it may represent a key driver for the development of policy oriented toward this purpose. Finally, a relevant emerging topic pertains to the relationship between migration and climate change. Our review suggests that agriculture plays an important role in mediating this nexus as climatic shocks negatively affect the primary sector, which represents the main source of income, especially in developing countries.

Overall, the contents of this review suggest one more time the importance of pursuing sustainable development. From this perspective, academic studies should give priority to the analysis of this topic, where perhaps a more interdisciplinary approach may lead to an improvement of current knowledge.

Author Contributions: The paper is the result of the collaboration among all authors; however, D.B., D.C., and R.P. contributed mainly to the section on "evolving agricultural and agro-energy policy toward a sustainability path"; G.F., D.F., and V.V. contributed mainly to the sections on "agbiotech innovation for sustainable agriculture" and "food waste reduction"; E.C.R. contributed mainly to the sections on "increasing the sustainability of food production" and on "consumer preferences for environmental sustainability attributes"; and F.D. contributed mainly to the section on "migration and climate change".

Funding: This research received no external funding.

Acknowledgments: The authors would like to thank the anonymous reviewers for providing insightful suggestions and comments.

Conflicts of Interest: The authors declare no conflicts of interest. 


\section{Appendix A}

Table A1. Summary of major findings, implications, and future research insights for the different topics analyzed.

\begin{tabular}{|c|c|c|c|}
\hline Topic & Main Findings & Implications & Future Research \\
\hline $\begin{array}{l}\text { Agricultural and agro-energy policy } \\
\text { toward a sustainability path }\end{array}$ & $\begin{array}{l}\text { Farm level agricultural policy schemes, } \\
\text { aimed at fostering environmental } \\
\text { sustainability, may lack territorial } \\
\text { targeting and weaken economic and } \\
\text { social sustainability in some areas. }\end{array}$ & $\begin{array}{l}\text { Such shortcomings may be addressed by } \\
\text { setting up a monitoring system to assess } \\
\text { ex-ante and ex-post impacts of agricultural } \\
\text { policy on the three pillars of sustainability }\end{array}$ & $\begin{array}{l}\text { Current indicators used to assess } \\
\text { agricultural sustainability should be } \\
\text { reinforced, through a better integration of } \\
\text { farm-level and territorial databases }\end{array}$ \\
\hline $\begin{array}{l}\text { Agbiotech innovation for } \\
\text { sustainable agriculture }\end{array}$ & $\begin{array}{l}\text { Increasing patenting activity over time, } \\
\text { innovation able to provide solutions for } \\
\text { a more sustainable production system }\end{array}$ & $\begin{array}{l}\text { Policies aimed at promoting the adoption } \\
\text { of NBT based products }\end{array}$ & $\begin{array}{l}\text { Identification of drivers/constraints } \\
\text { related to innovation capacity and } \\
\text { competitiveness and their impact } \\
\text { on productivity }\end{array}$ \\
\hline Food waste reduction & $\begin{array}{l}\text { Prevention is the most preferable option } \\
\text { from an economic and } \\
\text { environmental perspective }\end{array}$ & $\begin{array}{l}\text { Need to implement policy interventions } \\
\text { and incentives to decrease food waste } \\
\text { generation and promote re-use }\end{array}$ & $\begin{array}{l}\text { Models for the estimations of the economic } \\
\text { gains derived by the implementation of } \\
\text { different food waste reduction strategies }\end{array}$ \\
\hline $\begin{array}{l}\text { Increasing the sustainability of } \\
\text { food production }\end{array}$ & $\begin{array}{l}\text { Different production strategies can lead } \\
\text { to different impacts, reduction in meat } \\
\text { consumption is one of the most } \\
\text { effective solutions }\end{array}$ & $\begin{array}{l}\text { Measures to incentivize input-use } \\
\text { efficiency and resource protection and } \\
\text { promote the shift toward more sustainable } \\
\text { consumption patterns }\end{array}$ & $\begin{array}{l}\text { Assessment of the environmental and } \\
\text { economic costs associated with current } \\
\text { food production practices }\end{array}$ \\
\hline $\begin{array}{l}\text { Consumer preferences for } \\
\text { environmental sustainability attributes }\end{array}$ & $\begin{array}{l}\text { Growing concern among consumers } \\
\text { about the environmental impacts of their } \\
\text { everyday food choices. Not all } \\
\text { consumers are conscious and interested } \\
\text { in these aspects, and even those that are } \\
\text { concerned often do not take on } \\
\text { sustainable behaviors }\end{array}$ & $\begin{array}{l}\text { More effort in finding ways to better } \\
\text { communicate the impacts of day-by-day } \\
\text { food choices and in understanding the } \\
\text { motivations behind the } \\
\text { attitude-behavior gap }\end{array}$ & $\begin{array}{c}\text { Further studies should investigate how to } \\
\text { motivate different types of consumers so } \\
\text { that they can make more sustainable } \\
\text { choices reducing the environmental } \\
\text { impacts of the food system }\end{array}$ \\
\hline Migration and climate change & $\begin{array}{l}\text { Negative agricultural variations due to } \\
\text { an increase in temperature and } \\
\text { precipitations are possible motivations } \\
\text { behind the migration decision }\end{array}$ & $\begin{array}{l}\text { Socio-economic policies have to take into } \\
\text { account the fact that climate change may } \\
\text { induce more individuals to move }\end{array}$ & $\begin{array}{l}\text { Analysis of the relationship between } \\
\text { climate change, agricultural productivity, } \\
\text { conflicts, and migration so that a negative } \\
\text { impact of climate change on agricultural } \\
\text { productivity may generate conflicts, hence } \\
\text { may force human mobility }\end{array}$ \\
\hline
\end{tabular}




\section{References}

1. Martin, J.E. Agricultural Economics: A Critical Review of the State of the Science. J. Agric. Appl. Econ. 1978, 10,39-42. [CrossRef]

2. Shao, G.; Li, F.; Tang, L. Multidisciplinary perspectives on sustainable development. Int. J. Sustain. Dev. World Ecol. 2011, 18, 187-189. [CrossRef]

3. Cortese, A.D. The critical role of higher education in creating a sustainable future. Plan. High. Educ. 2003, 31, 15-22.

4. Jabareen, Y. Teaching Sustainability: A Multidisciplinary Approach. Creat. Educ. 2011, 2, 388-392. [CrossRef]

5. Wu, J.J. Landscape Ecology, Cross-Disciplinarity, and Sustainability Science; Springer: Berlin, Germany, 2006.

6. Glavič, P.; Lukman, R. Review of sustainability terms and their definitions. J. Clean. Prod. 2007, 15, 1875-1885. [CrossRef]

7. Mauerhofer, V. 3-D Sustainability: An approach for priority setting in situation of conflicting interests towards a Sustainable Development. Ecol. Econ. 2008, 64, 496-506. [CrossRef]

8. Smith, P.; Clark, H.; Dong, H.; Elsiddig, E.A.; Haberl, H.; Harper, R.; House, J.; Jafari, M.; Masera, O.; Mbow, C.; et al. Chapter 11-Agriculture, forestry and other land use (AFOLU). In Climate Change 2014: Mitigation of Climate Change. IPCC Working Group III Contribution to AR5; Cambridge University Press: Cambridge, UK, 2014.

9. World Commission on Environment and Development. Our Common Future; Oxford University Press: Oxford, UK; New York, NY, USA, 1987; ISBN 978-0-19-282080-8.

10. Defrancesco, E.; Gatto, P.; Runge, F.; Trestini, S. Factors affecting farmers' participation in agri-environmental measures: A Northern Italian perspective. J. Agric. Econ. 2008, 59, 114-131. [CrossRef]

11. Bertoni, D.; Cavicchioli, D.; Pretolani, R.; Olper, A. Agri-Environmental Measures Adoption: New Evidence from Lombardy Region. In The Common Agricultural Policy after the Fischler Reform; Routledge: Abingdon, UK, 2011; pp. 275-294.

12. Burton, R.J. The influence of farmer demographic characteristics on environmental behaviour: A review. J. Environ. Manag. 2014, 135, 19-26. [CrossRef]

13. Franzén, F.; Dinnétz, P.; Hammer, M. Factors affecting farmers' willingness to participate in eutrophication mitigation-A case study of preferences for wetland creation in Sweden. Ecol. Econ. 2016, 130, 8-15. [CrossRef]

14. Pavlis, E.S.; Terkenli, T.S.; Kristensen, S.B.; Busck, A.G.; Cosor, G.L. Patterns of agri-environmental scheme participation in Europe: Indicative trends from selected case studies. Land Use Policy 2016, 57, 800-812. [CrossRef]

15. Paracchini, M.L.; Bulgheroni, C.; Borreani, G.; Tabacco, E.; Banterle, A.; Bertoni, D.; Rossi, G.; Parolo, G.; Origgi, R.; De Paola, C. A diagnostic system to assess sustainability at a farm level: The SOSTARE model. Agric. Syst. 2015, 133, 35-53. [CrossRef]

16. De Olde, E.M.; Oudshoorn, F.W.; Sørensen, C.A.; Bokkers, E.A.; De Boer, I.J. Assessing sustainability at farm-level: Lessons learned from a comparison of tools in practice. Ecol. Indic. 2016, 66, 391-404. [CrossRef]

17. Zahm, F.; Viaux, P.; Vilain, L.; Girardin, P.; Mouchet, C. Assessing farm sustainability with the IDEA method-from the concept of agriculture sustainability to case studies on farms. Sustain. Dev. 2008, 16, 271-281. [CrossRef]

18. Bertoni, D.; Curzi, D.; Iacus, S.; Olper, A. Estimating the Causal Effect of Green Payments in Agriculture: The Coarsened Exact Matching; International Association of Agricultural Economists: Milwaukee, WI, USA, 2018.

19. Pufahl, A.; Weiss, C.R. Evaluating the effects of farm programmes: Results from propensity score matching. Eur. Rev. Agric. Econ. 2009, 36, 79-101. [CrossRef]

20. Chabé-Ferret, S.; Subervie, J. How much green for the buck? Estimating additional and windfall effects of French agro-environmental schemes by DID-matching. J. Environ. Econ. Manag. 2013, 65, 12-27. [CrossRef]

21. Olper, A.; Raimondi, V.; Cavicchioli, D.; Vigani, M. Do CAP payments reduce farm labour migration? A panel data analysis across EU regions. Eur. Rev. Agric. Econ. 2014, 41, 843-873. [CrossRef]

22. Giannakis, E.; Efstratoglou, S.; Antoniades, A. Off-Farm Employment and Economic Crisis: Evidence from Cyprus. Agriculture 2018, 8, 41. [CrossRef] 
23. Matthews, A. Greening agricultural payments in the EU's Common Agricultural Policy. Bio-Based Appl. Econ. 2013, 2, 1-27.

24. Gocht, A.; Ciaian, P.; Bielza, M.; Terres, J.-M.; Röder, N.; Himics, M.; Salputra, G. EU-wide Economic and Environmental Impacts of CAP Greening with High Spatial and Farm-type Detail. J. Agric. Econ. 2017, 68, 651-681. [CrossRef]

25. Louhichi, K.; Ciaian, P.; Espinosa, M.; Perni, A.; Gomez y Paloma, S. Economic impacts of CAP greening: Application of an EU-wide individual farm model for CAP analysis (IFM-CAP). Eur. Rev. Agric. Econ. 2017, 45, 205-238. [CrossRef]

26. Fumagalli, M.; Acutis, M.; Mazzetto, F.; Vidotto, F.; Sali, G.; Bechini, L. An analysis of agricultural sustainability of cropping systems in arable and dairy farms in an intensively cultivated plain. Eur. J. Agron. 2011, 34, 71-82. [CrossRef]

27. Cavicchioli, D.; Bertoni, D. Effects of Cap Green Payments in Lombardy: A Comparison of Proposed and Approved Measures Based on Census Data; Universitas Studiorum: Mantova, Italy, 2015; pp. 109-120.

28. Solazzo, R.; Pierangeli, F. How does greening affect farm behaviour? Trade-off between commitments and sanctions in the Northern Italy. Agric. Syst. 2016, 149, 88-98. [CrossRef]

29. Solazzo, R.; Donati, M.; Tomasi, L.; Arfini, F. How effective is greening policy in reducing GHG emissions from agriculture? Evidence from Italy. Sci. Total Environ. 2016, 573, 1115-1124. [CrossRef] [PubMed]

30. Cortignani, R.; Severini, S.; Dono, G. Complying with greening practices in the new CAP direct payments: An application on Italian specialized arable farms. Land Use Policy 2017, 61, 265-275. [CrossRef]

31. Gaudino, S.; Reidsma, P.; Kanellopoulos, A.; Sacco, D.; van Ittersum, M.K. Integrated Assessment of the EU's Greening Reform and Feed Self-Sufficiency Scenarios on Dairy Farms in Piemonte, Italy. Agriculture 2018, 8, 137. [CrossRef]

32. Bertoni, D.; Aletti, G.; Ferrandi, G.; Micheletti, A.; Cavicchioli, D.; Pretolani, R. Farmland Use Transitions After the CAP Greening: A Preliminary Analysis Using Markov Chains Approach. Land Use Policy 2018, 79, 789-800. [CrossRef]

33. Le Roy, D.G.; Klein, K.K. The policy objectives of a biofuel industry in Canada: An assessment. Agriculture 2012, 2, 436-451. [CrossRef]

34. Tokgoz, S.; Zhang, W.; Msangi, S.; Bhandary, P. Biofuels and the future of food: Competition and complementarities. Agriculture 2012, 2, 414-435. [CrossRef]

35. Bartoli, A.; Cavicchioli, D.; Kremmydas, D.; Rozakis, S.; Olper, A. The impact of different energy policy options on feedstock price and land demand for maize silage: The case of biogas in Lombardy. Energy Policy 2016, 96, 351-363. [CrossRef]

36. Demartini, E.; Gaviglio, A.; Gelati, M.; Cavicchioli, D. The Effect of Biogas Production on Farmland Rental Prices: Empirical Evidences from Northern Italy. Energies 2016, 9, 965. [CrossRef]

37. Pacini, C.; Giesen, G.; Wossink, A.; Omodei-Zorini, L.; Huirne, R. The EU's Agenda 2000 reform and the sustainability of organic farming in Tuscany: Ecological-economic modelling at field and farm level. Agric. Syst. 2004, 80, 171-197. [CrossRef]

38. Van Passel, S.; Nevens, F.; Mathijs, E.; Van Huylenbroeck, G. Measuring farm sustainability and explaining differences in sustainable efficiency. Ecol. Econ. 2007, 62, 149-161. [CrossRef]

39. Meul, M.; Nevens, F.; Reheul, D.; Hofman, G. Energy use efficiency of specialised dairy, arable and pig farms in Flanders. Agric. Ecosyst. Environ. 2007, 119, 135-144. [CrossRef]

40. Bechini, L.; Castoldi, N. On-farm monitoring of economic and environmental performances of cropping systems: Results of a 2-year study at the field scale in northern Italy. Ecol. Indic. 2009, 9, 1096-1113. [CrossRef]

41. Thomassen, M.A.; Dolman, M.A.; Van Calker, K.J.; De Boer, I.J.M. Relating life cycle assessment indicators to gross value added for Dutch dairy farms. Ecol. Econ. 2009, 68, 2278-2284. [CrossRef]

42. Ripoll-Bosch, R.; Díez-Unquera, B.; Ruiz, R.; Villalba, D.; Molina, E.; Joy, M.; Olaizola, A.; Bernués, A. An integrated sustainability assessment of mediterranean sheep farms with different degrees of intensification. Agric. Syst. 2012, 105, 46-56. [CrossRef]

43. Demartini, E.; Gaviglio, A.; Bertoni, D. Integrating agricultural sustainability into policy planning: A geo-referenced framework based on Rough Set theory. Environ. Sci. Policy 2015, 54, 226-239. [CrossRef] 
44. Kirchner, M.; Schmidt, J.; Kindermann, G.; Kulmer, V.; Mitter, H.; Prettenthaler, F.; Rüdisser, J.; Schauppenlehner, T.; Schönhart, M.; Strauss, F. Ecosystem services and economic development in Austrian agricultural landscapes-The impact of policy and climate change scenarios on trade-offs and synergies. Ecol. Econ. 2015, 109, 161-174. [CrossRef]

45. Paracchini, M.L.; Correia, T.P.; Loupa-Ramos, I.; Capitani, C.; Madeira, L. Progress in indicators to assess agricultural landscape valuation: How and what is measured at different levels of governance. Land Use Policy 2016, 53, 71-85. [CrossRef]

46. Palmgren, M.G.; Edenbrandt, A.K.; Vedel, S.E.; Andersen, M.M.; Landes, X.; Østerberg, J.T.; Falhof, J.; Olsen, L.I.; Christensen, S.B.; Sandøe, P.; et al. Are we ready for back-to-nature crop breeding? Trends Plant Sci. 2015, 20, 155-164. [CrossRef]

47. Lusser, M.; Parisi, C.; Plan, D.; Rodríguez-Cerezo, E. Deployment of new biotechnologies in plant breeding. Nat. Biotechnol. 2012, 30, 231-239. [CrossRef] [PubMed]

48. Andersen, M.M.; Landes, X.; Xiang, W.; Anyshchenko, A.; Falhof, J.; Østerberg, J.T.; Olsen, L.I.; Edenbrandt, A.K.; Vedel, S.E.; Thorsen, B.J.; et al. Feasibility of new breeding techniques for organic farming. Trends Plant Sci. 2015, 20, 426-434. [CrossRef] [PubMed]

49. Kissoudis, C.; van de Wiel, C.; Visser, R.G.; van der Linden, G. Future-proof crops: Challenges and strategies for climate resilience improvement. Curr. Opin. Plant Biol. 2016, 30, 47-56. [CrossRef] [PubMed]

50. Stenberg, J.A.; Heil, M.; Åhman, I.; Björkman, C. Optimizing Crops for Biocontrol of Pests and Disease. Trends Plant Sci. 2015, 20, 698-712. [CrossRef] [PubMed]

51. Shew, A.M.; Danforth, D.M.; Nalley, L.L.; Nayga, R.M.; Tsiboe, F.; Dixon, B.L. New innovations in agricultural biotech: Consumer acceptance of topical RNAi in rice production. Food Control 2017, 81, 189-195. [CrossRef]

52. Jefferson, O.A.; Jaffe, A.; Ashton, D.; Warren, B.; Koellhofer, D.; Dulleck, U.; Ballagh, A.; Moe, J.; DiCuccio, M.; Ward, K.; et al. Mapping the global influence of published research on industry and innovation. Nat. Biotechnol. 2018, 36, 31-39. [CrossRef]

53. Clancy, M.S.; Moschini, G. Intellectual Property Rights and the Ascent of Proprietary Innovation in Agriculture. Annu. Rev. Resour. Econ. 2017, 9, 53-74. [CrossRef]

54. Zilberman, D.; Gordon, B.; Hochman, G.; Wesseler, J. Economics of Sustainable Development and the Bioeconomy. Appl. Econ. Perspect. Policy 2018, 40, 22-37. [CrossRef]

55. Haščič, I.; Migotto, M. Measuring Environmental Innovation Using Patent Data; OECD: Paris, France, 2015.

56. Haščič, I.; Silva, J.; Johnstone, N. The Use of Patent Statistics for International Comparisons and Analysis of Narrow Technological Fields; OECD: Paris, France, 2015.

57. Graff, G.D.; Cullen, S.E.; Bradford, K.J.; Zilberman, D.; Bennett, A.B. The public-private structure of intellectual property ownership in agricultural biotechnology. Nat. Biotechnol. 2003, 21, 989-995. [CrossRef]

58. Frisio, D.G.; Ferrazzi, G.; Ventura, V.; Vigani, M. Public vs. Private Agbiotech Research in the United States and European Union, 2002-2009. AgBioForum 2010, 13, 333-342.

59. Egelie, K.J.; Graff, G.D.; Strand, S.P.; Johansen, B. The emerging patent landscape of CRISPR-Cas gene editing technology. Nat. Biotechnol. 2016, 34, 1025-1031. [CrossRef] [PubMed]

60. Khan, S.S.; Timotijevic, L.; Newton, R.; Coutinho, D.; Llerena, J.L.; Ortega, S.; Benighaus, L.; Hofmaier, C.; Xhaferri, Z.; de Boer, A. The framing of innovation among European research funding actors: Assessing the potential for 'responsible research and innovation'in the food and health domain. Food Policy 2016, 62, 78-87. [CrossRef]

61. Eriksson, M.; Strid, I.; Hansson, P.-A. Carbon footprint of food waste management options in the waste hierarchy-a Swedish case study. J. Clean. Prod. 2015, 93, 115-125. [CrossRef]

62. Reynolds, C.J.; Piantadosi, J.; Boland, J. Rescuing Food from the Organics Waste Stream to Feed the Food Insecure: An Economic and Environmental Assessment of Australian Food Rescue Operations Using Environmentally Extended Waste Input-Output Analysis. Sustainability 2015, 7, 4707-4726. [CrossRef]

63. Bellemare, M.F.; Çakir, M.; Peterson, H.H.; Novak, L.; Rudi, J. On the Measurement of Food Waste. Am. J. Agric. Econ. 2017, 99, 1148-1158. [CrossRef]

64. Garrone, P.; Melacini, M.; Perego, A. Opening the black box of food waste reduction. Food Policy 2014, 46, 129-139. [CrossRef] 
65. Papargyropoulou, E.; Lozano, R.; Steinberger, J.K.; Wright, N.; bin Ujang, Z. The food waste hierarchy as a framework for the management of food surplus and food waste. J. Clean. Prod. 2014, 76, 106-115. [CrossRef]

66. Garcia-Herrero, I.; Hoehn, D.; Margallo, M.; Laso, J.; Bala, A.; Batlle-Bayer, L.; Fullana, P.; Vazquez-Rowe, I.; Gonzalez, M.J.; Durá, M.J. On the estimation of potential food waste reduction to support sustainable production and consumption policies. Food Policy 2018, 80, 24-38. [CrossRef]

67. Chegere, M.J. Post-harvest losses reduction by small-scale maize farmers: The role of handling practices. Food Policy 2018, 77, 103-115. [CrossRef]

68. Balzaretti, C.M.; Ventura, V.; Ratti, S.; Ferrazzi, G.; Spallina, A.; Carruba, M.O.; Castrica, M. Improving the overall sustainability of the school meal chain: The role of portion sizes. Eat Weight Disord. 2018. [CrossRef]

69. Vittuari, M.; De Menna, F.; Gaiani, S.; Falasconi, L.; Politano, A.; Dietershagen, J.; Segrè, A. The Second Life of Food: An Assessment of the Social Impact of Food Redistribution Activities in Emilia Romagna, Italy. Sustainability 2017, 9, 1817. [CrossRef]

70. Schneider, F. The evolution of food donation with respect to waste prevention. Waste Manag. 2013, 33, 755-763. [CrossRef] [PubMed]

71. Stepman, E.; Uyttendaele, M.; De Boeck, E.; Jacxsens, L. Needs of beneficiaries related to the format and content of food parcels in Ghent, Belgium. Br. Food J. 2018, 120, 578-587. [CrossRef]

72. Mourad, M. Recycling, recovering and preventing "food waste": Competing solutions for food systems sustainability in the United States and France. J. Clean. Prod. 2016, 126, 461-477. [CrossRef]

73. Directive 2008/98/EC of the European Parliament and of the Council of 19 November 2008 on Waste and Repealing Certain Directives (Text with EEA Relevance); European Union: Brussels, Belgium, 2008; Volume 034, pp. 99-126.

74. Regulation (EC) No 1069/2009 of the European Parliament and of the Council of 21 October 2009 Laying down Health Rules as Regards Animal by-Products and Derived Products not Intended for Human Consumption and Repealing Regulation (EC) No 1774/2002 (Animal by-Products Regulation); European Parliament: Brussels, Belgium, 2009; Volume 300.

75. Zu Ermgassen, E.K.H.J.; Phalan, B.; Green, R.E.; Balmford, A. Reducing the land use of EU pork production: Where there's a will, there's a way. Food Policy 2016, 58, 35-48. [CrossRef] [PubMed]

76. Salemdeeb, R.; zu Ermgassen, E.K.H.J.; Kim, M.H.; Balmford, A.; Al-Tabbaa, A. Environmental and health impacts of using food waste as animal feed: A comparative analysis of food waste management options. J. Clean. Prod. 2017, 140, 871-880. [CrossRef]

77. Castrica, M.; Tedesco, D.E.A.; Panseri, S.; Ferrazzi, G.; Ventura, V.; Frisio, D.G.; Balzaretti, C.M. Pet Food as the Most Concrete Strategy for Using Food Waste as Feedstuff within the European Context: A Feasibility Study. Sustainability 2018, 10, 2035. [CrossRef]

78. Kasapidou, E.; Sossidou, E.; Mitlianga, P. Fruit and Vegetable Co-Products as Functional Feed Ingredients in Farm Animal Nutrition for Improved Product Quality. Agriculture 2015, 5, 1020-1034. [CrossRef]

79. Stranieri, S.; Orsi, L.; Banterle, A.; Ricci, E.C. Sustainable development and supply chain coordination: The impact of corporate social responsibility rules in the European Union food industry. Corp. Soc. Responsib. Environ. Manag. 2018. [CrossRef]

80. Banterle, A.; Ricci, E.C.; Cavaliere, A. Environmental sustainability and the food system. In Regulating Food Safety Law in the EU-A Management and Economics Perspective; Bremmers, H.J., Purnhagen, K., Eds.; Springer: Basel, Switzerland, 2018.

81. Cole, C.V.; Duxbury, J.; Freney, J.; Heinemeyer, O.; Minami, K.; Mosier, A.; Paustian, K.; Rosenberg, N.; Sampson, N.; Sauerbeck, D.; et al. Global estimates of potential mitigation of greenhouse gas emissions by agriculture. Nutr. Cycl. Agroecosyst. 1997, 49, 221-228. [CrossRef]

82. Valdez, V.; Berger, J.D.; Warkentin, T.; Asseng, S.; Ratnakumar, P.; Rao, K.P.C.; Gaur, P.M.; Munier-Jolain, N.; Larmure, A.; Voisin, A.S. Adaptation of grain legumes to climatic change: A review. Agron. Sustain. Dev. 2012, 32, 31-44. [CrossRef]

83. Bruinsma, J. World Agriculture: Towards 2015/2030: An FAO Study; Routledge: Abingdon, UK, 2017.

84. Delgado, C.; Rosegrant, M.; Steinfeld, H.; Ehui, S.; Courbois, C. Livestock to 2020: The Next Food Revolution. Outlook Agric. 2001, 30, 27-29. [CrossRef]

85. De Vries, M.; de Boer, I.J. Comparing environmental impacts for livestock products: A review of life cycle assessments. Livest. Sci. 2010, 128, 1-11. [CrossRef] 
86. Presumido, P.H.; Sousa, F.; Gonçalves, A.; Dal Bosco, T.C.; Feliciano, M. Environmental Impacts of the Beef Production Chain in the Northeast of Portugal Using Life Cycle Assessment. Agriculture 2018, 8, 165. [CrossRef]

87. Garnett, T. Livestock-related greenhouse gas emissions: Impacts and options for policy makers. Environ. Sci. Policy 2009, 12, 491-503. [CrossRef]

88. Steinfeld, H.; Gerber, P.; Wassenaar, T.D.; Castel, V.; Rosales, M.; Rosales, M.; de Haan, C. Livestock's Long Shadow: Environmental Issues and Options; Food \& Agriculture Organization: Rome, Italy, 2006.

89. Vermeir, I.; Verbeke, W. Sustainable Food Consumption: Exploring the Consumer "Attitude-Behavioral Intention" Gap. J. Agric. Environ. Ethics 2006, 19, 169-194.

90. Crosson, P.; Shalloo, L.; O’Brien, D.; Lanigan, G.J.; Foley, P.A.; Boland, T.M.; Kenny, D.A. A review of whole farm systems models of greenhouse gas emissions from beef and dairy cattle production systems. Anim. Feed Sci. Technol. 2011, 166, 29-45. [CrossRef]

91. Capper, J.L. The environmental impact of beef production in the United States: 1977 compared with 2007. J. Anim. Sci. 2011, 89, 4249-4261. [CrossRef] [PubMed]

92. Pelletier, N.; Pirog, R.; Rasmussen, R. Comparative life cycle environmental impacts of three beef production strategies in the Upper Midwestern United States. Agric. Syst. 2010, 103, 380-389. [CrossRef]

93. Casey, J.W.; Holden, N.M. Greenhouse Gas Emissions from Conventional, Agri-Environmental Scheme, and Organic Irish Suckler-Beef Units. J. Environ. Qual. 2006, 35, 231-239. [CrossRef] [PubMed]

94. Garnett, T. Where are the best opportunities for reducing greenhouse gas emissions in the food system (including the food chain)? Food Policy 2011, 36, S23-S32. [CrossRef]

95. Micha, R.; Wallace, S.K.; Mozaffarian, D. Red and processed meat consumption and risk of incident coronary heart disease, stroke, and diabetes: A systematic review and meta-analysis. Circulation 2010, 121, 2271-2283. [CrossRef]

96. Bouvard, V.; Loomis, D.; Guyton, K.Z.; Grosse, Y.; El Ghissassi, F.; Benbrahim-Tallaa, L.; Guha, N.; Mattock, H.; Kurt, S. Carcinogenicity of consumption of red and processed meat-Google Scholar. Lancet Oncol. 2015, 16, 1599-1600. [CrossRef]

97. Ricci, E.C.; Banterle, A. The effects of EXPO MIlano 2015 on consumer food choices. Econ. Ago-Aliment. Food Econ. 2018, 20, 233-244. [CrossRef]

98. Grunert, K.G. Sustainability in the Food Sector: A Consumer Behaviour Perspective. Int. J. Food Syst. Dyn. 2011, 2, 207-218.

99. Evans, D. Consuming conventions: Sustainable consumption, ecological citizenship and the worlds of worth. J. Rural. Stud. 2011, 27, 109-115. [CrossRef]

100. Cavaliere, A.; Ventura, V. Mismatch between food sustainability and consumer acceptance toward innovation technologies among Millennial students: The case of Shelf Life Extension. J. Clean. Prod. 2018, 175, 641-650. [CrossRef]

101. Coppola, A.; Verneau, F. An empirical analysis on technophobia/technophilia in consumer market segmentation. Agric. Food Econ. 2014, 2, 2. [CrossRef]

102. Grunert, K.G.; Hieke, S.; Wills, J. Sustainability labels on food products: Consumer motivation, understanding and use. Food Policy 2014, 44, 177-189. [CrossRef]

103. Grebitus, C.; Steiner, B.; Veeman, M.M. Paying for sustainability: A cross-cultural analysis of consumers' valuations of food and non-food products labeled for carbon and water footprints. J. Behav. Exp. Econ. 2016, 63, 50-58. [CrossRef]

104. Grolleau, G.; Caswell, J.A. Interaction between Food Attributes in Markets: The Case of Environmental Labeling. J. Agric. Resour. Econ. 2006, 31, 471-484. [CrossRef]

105. Krystallis, A.; Grunert, K.G.; de Barcellos, M.D.; Perrea, T.; Verbeke, W. Consumer attitudes towards sustainability aspects of food production: Insights from three continents. J. Mark. Manag. 2012, 28, 334-372. [CrossRef]

106. Asioli, D.; Næs, T.; Granli, B.S.; Lengard Almli, V. Consumer preferences for iced coffee determined by conjoint analysis: An exploratory study with $\mathrm{N}$ orwegian consumers. Int. J. Food Sci. Technol. 2014, 49, 1565-1571. [CrossRef]

107. Hu, W.; Hünnemeyer, A.; Veeman, M.; Adamowicz, W.; Srivastava, L. Trading off health, environmental and genetic modification attributes in food. Eur. Rev. Agric. Econ. 2004, 31, 389-408. [CrossRef] 
108. Caputo, V.; Nayga, R.M.; Scarpa, R. Food miles or carbon emissions? Exploring labelling preference for food transport footprint with a stated choice study. Aust. J. Agric. Resour. Econ. 2013, 57, 465-482. [CrossRef]

109. Akaichi, F.; Nayga, R.M.; Nalley, L.L. Are there trade-offs in valuation with respect to greenhouse gas emissions, origin and food miles attributes? Eur. Rev. Agric. Econ. 2017, 44, 3-31. [CrossRef]

110. Feucht, Y.; Zander, K. Consumers' preferences for carbon labels and the underlying reasoning. A mixed methods approach in 6 European countries. J. Clean. Prod. 2018, 178, 740-748. [CrossRef]

111. Ajzen, I. The theory of planned behavior. Organ. Behav. Hum. Decis. Process. 1991, 50, 179-211. [CrossRef]

112. Cerri, J.; Testa, F.; Rizzi, F. The more I care, the less I will listen to you: How information, environmental concern and ethical production influence consumers' attitudes and the purchasing of sustainable products. J. Clean. Prod. 2018, 175, 343-353. [CrossRef]

113. De Groot, J.; Steg, L. General Beliefs and the Theory of Planned Behavior: The Role of Environmental Concerns in the TPB. J. Appl. Soc. Psychol. 2007, 37, 1817-1836. [CrossRef]

114. Govindasamy, R.; Italia, J.; Adelaja, A. Predicting willingness-to-pay a premium for integrated pest management produce: A logistic approach. Agric. Resour. Econ. Rev. 2001, 30, 151-159. [CrossRef]

115. Ohtomo, S.; Hirose, Y. The dual-process of reactive and intentional decision-making involved in eco-friendly behavior. J. Environ. Psychol. 2007, 27, 117-125. [CrossRef]

116. Hobbs, J.E.; Goddard, E. Consumers and trust. Food Policy 2015, 52, 71-74. [CrossRef]

117. Lassoued, R.; Hobbs, J.E. Consumer confidence in credence attributes: The role of brand trust. Food Policy 2015, 52, 99-107. [CrossRef]

118. Nuttavuthisit, K.; Thøgersen, J. The importance of consumer trust for the emergence of a market for green products: The case of organic food. J. Bus. Ethics 2017, 140, 323-337. [CrossRef]

119. Ricci, E.C.; Banterle, A.; Stranieri, S. Trust to Go Green: An Exploration of Consumer Intentions for Eco-friendly Convenience Food. Ecol. Econ. 2018, 148, 54-65. [CrossRef]

120. Brunner, T.A.; van der Horst, K.; Siegrist, M. Convenience food products. Drivers for consumption. Appetite 2010, 55, 498-506. [CrossRef] [PubMed]

121. Olsen, N.V. The convenience consumer's dilemma. Br. Food J. 2012, 114, 1613-1625. [CrossRef]

122. Thaler, R.; Sunstein, C. Nudge: The Gentle Power of Choice Architecture; Yale: New Haven, CT, USA, 2008.

123. Bacon, L.; Krpan, D. (Not) Eating for the environment: The impact of restaurant menu design on vegetarian food choice. Appetite 2018, 125, 190-200. [CrossRef] [PubMed]

124. Kurz, V. Nudging to reduce meat consumption: Immediate and persistent effects of an intervention at a university restaurant. J. Environ. Econ. Manag. 2018, 90, 317-341. [CrossRef]

125. De Boer, J.; Schösler, H.; Aiking, H. "Meatless days" or "less but better"? Exploring strategies to adapt Western meat consumption to health and sustainability challenges. Appetite 2014, 76, 120-128. [CrossRef] [PubMed]

126. Filimonau, V.; Lemmer, C.; Marshall, D.; Bejjani, G. 'Nudging' as an architect of more responsible consumer choice in food service provision: The role of restaurant menu design. J. Clean. Prod. 2017, 144, 161-170. [CrossRef]

127. Menapace, L.; Raffaelli, R. Preferences for locally grown products: Evidence from a natural field experiment. Eur. Rev. Agric. Econ. 2017, 44, 255-284. [CrossRef]

128. Brunner, F.; Kurz, V.; Bryngelsson, D.; Hedenus, F. Carbon Label at a University Restaurant-Label Implementation and Evaluation. Ecol. Econ. 2018, 146, 658-667. [CrossRef]

129. Aertsens, J.; Verbeke, W.; Mondelaers, K.; Huylenbroeck, G.V. Personal determinants of organic food consumption: A review. Br. Food J. 2009, 111, 1140-1167. [CrossRef]

130. Agovino, M.; Crociata, A.; Quaglione, D.; Sacco, P.; Sarra, A. Good Taste Tastes Good. Cultural Capital as a Determinant of Organic Food Purchase by Italian Consumers: Evidence and Policy Implications. Ecol. Econ. 2017, 141, 66-75. [CrossRef]

131. Arvola, A.; Vassallo, M.; Dean, M.; Lampila, P.; Saba, A.; Lähteenmäki, L.; Shepherd, R. Predicting intentions to purchase organic food: The role of affective and moral attitudes in the Theory of Planned Behaviour. Appetite 2008, 50, 443-454. [CrossRef]

132. Gerini, F.; Alfnes, F.; Schjøll, A. Organic-and Animal Welfare-labelled Eggs: Competing for the Same Consumers? J. Agric. Econ. 2016, 67, 471-490. [CrossRef] 
133. Zanoli, R.; Scarpa, R.; Napolitano, F.; Piasentier, E.; Naspetti, S.; Bruschi, V. Organic label as an identifier of environmentally related quality: A consumer choice experiment on beef in Italy. Renew. Agric. Food Syst. 2013, 28, 70-79. [CrossRef]

134. Alfnes, F. Selling only sustainable seafood: Attitudes toward public regulation and retailer policies. Mar. Policy 2017, 78, 74-79. [CrossRef]

135. Roheim, C.A.; Asche, F.; Santos, J.I. The elusive price premium for ecolabelled products: Evidence from seafood in the UK market. J. Agric. Econ. 2011, 62, 655-668. [CrossRef]

136. Uchida, H.; Onozaka, Y.; Morita, T.; Managi, S. Demand for ecolabeled seafood in the Japanese market: A conjoint analysis of the impact of information and interaction with other labels. Food Policy 2014, 44, 68-76. [CrossRef]

137. Caracciolo, F.; Cicia, G.; Del Giudice, T.; Cembalo, L.; Krystallis, A.; Grunert, K.G.; Lombardi, P. Human values and preferences for cleaner livestock production. J. Clean. Prod. 2016, 112, 121-130. [CrossRef]

138. Pomarici, E.; Vecchio, R. Millennial generation attitudes to sustainable wine: An exploratory study on Italian consumers. J. Clean. Prod. 2014, 66, 537-545. [CrossRef]

139. Van Loo, E.J.; Caputo, V.; Nayga, R.M.; Seo, H.-S.; Zhang, B.; Verbeke, W. Sustainability labels on coffee: Consumer preferences, willingness-to-pay and visual attention to attributes. Ecol. Econ. 2015, 118, 215-225. [CrossRef]

140. Van Loo, E.J.; Caputo, V.; Nayga, R.M.; Verbeke, W. Consumers' valuation of sustainability labels on meat. Food Policy 2014, 49, 137-150. [CrossRef]

141. Vecchio, R.; Annunziata, A. Willingness-to-pay for sustainability-labelled chocolate: An experimental auction approach. J. Clean. Prod. 2015, 86, 335-342. [CrossRef]

142. Apostolidis, C.; McLeay, F. Should we stop meating like this? Reducing meat consumption through substitution. Food Policy 2016, 65, 74-89. [CrossRef]

143. Hoek, A.C.; Pearson, D.; James, S.W.; Lawrence, M.A.; Friel, S. Shrinking the food-print: A qualitative study into consumer perceptions, experiences and attitudes towards healthy and environmentally friendly food behaviours. Appetite 2017, 108, 117-131. [CrossRef]

144. Mullee, A.; Vermeire, L.; Vanaelst, B.; Mullie, P.; Deriemaeker, P.; Leenaert, T.; De Henauw, S.; Dunne, A.; Gunter, M.J.; Clarys, P.; et al. Vegetarianism and meat consumption: A comparison of attitudes and beliefs between vegetarian, semi-vegetarian, and omnivorous subjects in Belgium. Appetite 2017, 114, $299-305$. [CrossRef]

145. Vainio, A.; Niva, M.; Jallinoja, P.; Latvala, T. From beef to beans: Eating, motives and the replacement of animal proteins with plant proteins among Finnish consumers. Appetite 2016, 106, 92-100. [CrossRef] [PubMed]

146. Reynolds, C.J.; Mirosa, M.; Clothier, B. New Zealand's Food Waste: Estimating the Tonnes, Value, Calories and Resources Wasted. Agriculture 2016, 6, 9. [CrossRef]

147. Blanke, M. Challenges of Reducing Fresh Produce Waste in Europe-From Farm to Fork. Agriculture 2015, 5, 389-399. [CrossRef]

148. Secondi, L.; Principato, L.; Laureti, T. Household food waste behaviour in EU-27 countries: A multilevel analysis. Food Policy 2015, 56, 25-40. [CrossRef]

149. Stancu, V.; Haugaard, P.; Lähteenmäki, L. Determinants of consumer food waste behaviour: Two routes to food waste. Appetite 2016, 96, 7-17. [CrossRef] [PubMed]

150. Neff, R.A.; Spiker, M.L.; Truant, P.L. Wasted food: US consumers' reported awareness, attitudes, and behaviors. PLoS ONE 2015, 10, e0127881. [CrossRef] [PubMed]

151. Hebrok, M.; Boks, C. Household food waste: Drivers and potential intervention points for design-An extensive review. J. Clean. Prod. 2017, 151, 380-392. [CrossRef]

152. Toma, L.; Costa Font, M.; Thompson, B. Impact of consumers' understanding of date labelling on food waste behaviour. Oper. Res. 2017, 1-18. [CrossRef]

153. Thompson, B.; Toma, L.; Barnes, A.P.; Revoredo-Giha, C. The effect of date labels on willingness to consume dairy products: Implications for food waste reduction. Waste Manag. 2018, 78, 124-134. [CrossRef]

154. Aschemann-Witzel, J.; Niebuhr Aagaard, E.M. Elaborating on the attitude-behaviour gap regarding organic products: Young Danish consumers and in-store food choice: In-store organic food choice. Int. J. Consum. Stud. 2014, 38, 550-558. [CrossRef] 
155. Godin, G.; Conner, M.; Sheeran, P. Bridging the intention-behaviour gap: The role of moral norm. Br. J. Soc. Psychol. 2005, 44, 497-512. [CrossRef] [PubMed]

156. Cai, R.; Feng, S.; Oppenheimer, M.; Pytlikova, M. Climate variability and international migration: The importance of the agricultural linkage. J. Environ. Econ. Manag. 2016, 79, 135-151. [CrossRef]

157. Kubik, Z.; Maurel, M. Weather shocks, agricultural production and migration: Evidence from Tanzania. J. Dev. Stud. 2016, 52, 665-680. [CrossRef]

158. Nawrotzki, R.J.; Hunter, L.M.; Runfola, D.M.; Riosmena, F. Climate change as a migration driver from rural and urban Mexico. Environ. Res. Lett. 2015, 10, 114023. [CrossRef] [PubMed]

159. Todaro, M.P. A model of labor migration and urban unemployment in less developed countries. Am. Econ. Rev. 1969, 59, 138-148.

160. Harris, J.R.; Todaro, M.P. Migration, unemployment and development: A two-sector analysis. Am. Econ. Rev. 1970, 60, 126-142.

161. Stark, O.; Stark, O. The Migration of Labor; Wiley: Hoboken, NJ, USA, 1991.

162. Drabo, A.; Mbaye, L.M. Natural disasters, migration and education: An empirical analysis in developing countries. Environ. Dev. Econ. 2015, 20, 767-796. [CrossRef]

163. Falco, C.; Donzelli, F.; Olper, A. Climate Change, Agriculture and Migration: A Survey. Sustainability 2018, 10, 1405. [CrossRef]

164. Mendelsohn, R.; Nordhaus, W.D.; Shaw, D. The Impact of Global Warming on Agriculture: A Ricardian Analysis. Am. Econ. Rev. 1994, 84, 753-771.

165. Mendelsohn, R.O.; Massetti, E. The use of cross-sectional analysis to measure climate impacts on agriculture: Theory and evidence. Rev. Environ. Econ. Policy 2017, 11, 280-298. [CrossRef]

166. Dell, M.; Jones, B.F.; Olken, B.A. Temperature and Income: Reconciling New Cross-Sectional and Panel Estimates; National Bureau of Economic Research: Cambridge, MA, USA, 2009.

167. Falco, C.; Galeotti, M.; Olper, A. Climate change and Migration: Is Agriculture the Main Channel? IEFE Working Papers; IEFE, Center for Research on Energy and Environmental Economics and Policy, Universita' Bocconi: Milano, Italy, 2018.

168. Cattaneo, C.; Peri, G. The migration response to increasing temperatures. J. Dev. Econ. 2016, 122, $127-146$. [CrossRef]

169. Auffhammer, M.; Schlenker, W. Empirical studies on agricultural impacts and adaptation. Energy Econ. 2014, 46, 555-561. [CrossRef]

170. FAO. Reducing Vulnerabilities and Enhancing Resilience; United Nations: New York, NY, USA, 2017.

171. Lobell, D.B.; Bänziger, M.; Magorokosho, C.; Vivek, B. Nonlinear heat effects on African maize as evidenced by historical yield trials. Nat. Clim. Chang. 2011, 1, 42-45. [CrossRef]

172. Lobell, D.B.; Schlenker, W.; Costa-Roberts, J. Climate trends and global crop production since 1980. Science 2011, 333, 616-620. [CrossRef] [PubMed]

173. Hsiang, S.M.; Burke, M.; Miguel, E. Quantifying the Influence of Climate on Human Conflict. Science 2013, 341, 1235367. [CrossRef] [PubMed]

174. Hsiang, S.M.; Burke, M. Climate, conflict, and social stability: What does the evidence say? Clim. Chang. 2014, 123, 39-55. [CrossRef]

175. Cattaneo, C.; Bosetti, V. Climate-induced International Migration and Conflicts. CESifo Econ. Stud. 2017, 63, 500-528. [CrossRef]

176. Helpman, E.; Melitz, M.; Rubinstein, Y. Estimating Trade Flows: Trading Partners and Trading Volumes. Q. J. Econ. 2008, 123, 441-487. [CrossRef]

177. Missirian, A.; Schlenker, W. Asylum applications respond to temperature fluctuations. Science 2017, 358, 1610-1614. [CrossRef]

178. Bazzi, S. Wealth Heterogeneity and the Income Elasticity of Migration. Am. Econ. J. Appl. Econ. 2017, 9, 219-255. [CrossRef]

(c) 2018 by the authors. Licensee MDPI, Basel, Switzerland. This article is an open access article distributed under the terms and conditions of the Creative Commons Attribution (CC BY) license (http:/ / creativecommons.org/licenses/by/4.0/). 